\title{
它运只A
}

Review

\section{The use of adapted boxing as a rehabilitation strategy in people with diverse health conditions: a systematic review.}

\author{
Miguel A. Sánchez-Lastra ${ }^{1 *}$, Carlos A yán ${ }^{2}$, Mesut Sener ${ }^{3}$ and José M. Cancela ${ }^{1}$
}

Received: $17^{\text {th }}$ October 2018; A ccepted: 17th February 2020; Published: $29^{\text {th }}$ February 2020

\begin{abstract}
A bstract: Boxing exercise programs without direct contact with an opponent, is an adapted physical activity that integrate a series of tasks that may have positive effects on people with diverse health conditions. This study aimed to analyze the scientific evidence available on the effects of using adapted boxing as a rehabilitation strategy on people with diverse health conditions. A systematic review of the scientific literature was performed on studies which dealt with the effects of boxing as a rehabilitation strategy in people with diverse health conditions. Two modified scales were applied to assess the methodological quality of the findings. A total of 10 studies were included in the analysis, 4 of them were experimental and 6 observational. None of the studies reported injuries or other health complications derived from the exercise programs. The interventions led to improvements in cardiovascular fitness, upper body strength, body composition, coordination, gait independence and gait speed. The performance of adapted boxing is beneficial for people with diverse health conditions. Future randomized trials with larger samples would be needed to determine the most appropriate therapeutic dosing for each population.
\end{abstract}

Keywords: health and well-being; evidence-based practice; disability management

\section{Introduction}

People with diverse health conditions experience changes in body functions and structures arising from different disorders that can result in impairments, activity limitations or participation restrictions (Ü stün, Chatterrji, Kostansjek, \& Bickenbach, 2003). If difficulties exist in any of these three areas, it is considered disability by the International Classification of Functioning, Disability and $\mathrm{H}$ ealth (W orld $\mathrm{H}$ ealth O rganization, 2001). The performance of physical exercise is considered a safe, low-cost, non-pharmacological alternative which may prove useful in the rehabilitation processes of people with diverse health conditions (Pedersen $\&$ Saltin, 2015).

Traditionally, rehabilitation strategies have been based on physical exercise and were focused on aerobic and resistance exercise (Johannsen et al., 2016; Penedo \& Dahn, 2005). H owever, over the last few years, numerous alternative modalities have emerged and its effects have undergone research, as was the case with Pilates (Byrnes, Wu, \& W Willier, 2018), some varieties of martial arts (Jahnke, Larkey, Rogers, Etnier, \& Lin, 2010), dancing (Strassel, Cherkin, Steuten, Sherman, \& V rijhoef, 2011) or yoga (Ross \& Thomas, 2010), among others. All these modalities have been the object of scrutiny and revision, which has led to productive scientific discussions to consider the implementation of these modalities in the exercise programs for different populations.

One of the most recent rehabilitation strategy proposals which could lead to beneficial effects on people with diverse health conditions consists in boxing without direct contact with an opponent exercise programs, adapted to the particularities of each health condition. This modality integrates a 
series of tasks which may have a positive impact on diverse components of the practitioners' physical condition (Chaabène et al., 2015). It should be noted that boxing could also be performed virtually, using active video games (AVGs) which, in addition to the positive effects on the player's health, it also boosts adherence( $N$ augle, N augle, $\&$ W ikstrom, 2014; Sanders et al., 2015). A dherence is a crucial aspect for the success of the physical rehabilitation program (Rhodes \& Fiala, 2009). Furthermore, previous studies have shown the feasibility of these adapted interventions (Lee, Psotta, $\&$ Vagaja, 2016).

Due to the interesting characteristics of boxing without contact or performed virtually in these populations, it is important that health and rehabilitation professionals can easily access all existing evidence regarding its effects (Dijkers, M urphy $\&$ Krellman, 2012). This is particularly important in order to have the knowledge on how to prescribe and adapt the boxing programs to meet the requirements of each health condition, as well as the personal needs and abilities of specific individuals. These objectives can be achieved by conducting systematic reviews that synthesize the scientific knowledge available on the subject (H iggins \& Green, 2008).

Despite the apparent benefits of therapies based on adapted boxing, to the authors' knowledge, no systematic review has analyzed the efficacy and usefulness of real or virtual adapted boxing as a rehabilitation strategy in people with diverse health conditions. In addition, the absence of scientific evidence on its feasibility and safety at the time of implementing practical therapeutic interventions may contribute to a false perception of danger and to the users' predisposition towards reticence or rejection (Hermand, M ullet, \& Rompteaux, 1999). For this reason, the present systematic review aimed to analyze the research focused on the impact of boxing in people with diverse health conditions. The objective is to provide updated information, which might be of interest to health professionals and practitioners responsible for prescribing physical exercise as part of a rehabilitation process.

\section{Materials and Methods}

\section{Search strategy}

A systematic review of studies focused on boxing as a rehabilitation strategy in people with different health conditions was carried out by searching PubM ed, Cochrane D atabase of Systematic Reviews, Scopus, SportDiscus and Dialnet up to July 2018. The search was based on the Population, Intervention, Comparison and Outcome (PICO) strategy. Following the recommendations from Cochrane's Handbook for Systematic Reviews of Interventions (Higgins \& Green, 2008), only terms regarding the population and intervention were used, in a combination of standardized M eSH and freetext terms. Therefore, the following combination of keywords and Boolean operators was applied: "boxing" AND "therapy" OR "rehabilitation" OR "physical disability". Additional searches of relevant references within included articles or different systematic reviews were performed manually.

\section{Study selection and inclusion criteria}

Following the PICO strategy, the inclusion criteria were: a) to perform physical exercise programs based on boxing as a rehabilitation strategy in people with diverse health conditions related to impairments, following the International Classification of Functioning, Disability and $\mathrm{H}$ ealth (W orld Health Organization, 2001); b) to report the specific effects of such practices; and, c) to be published in English, Spanish or Portuguese. There were no restrictions regarding age or the types of health conditions. Those interventions in which boxing was part of a combined therapy whose effects were not reported separately were excluded.

Two reviewers (MSL and MS) examined the titles and abstracts of each item independently and created a draft list of eligiblestudies. A fter an independent examination of the full text, both reviewers compared their results to produce a final selection. In case of disagreement, the opinion of a third reviewer was requested (CA). 


\section{D ata analysis}

Reviewers gathered their own data independently once they finished reading the full text of each potentially eligible study. Attention was paid to the general objectives, variables under analysis, instruments, number of participants, age, types of interventions included in the study, number of dropouts, adherence and results obtained after the intervention.

The methodological quality of each study was assessed by two reviewers (MSL and CA). The opinion of a third reviewer (JC) was requested in case of disagreement. For studies which tested the effect of boxing as a rehabilitation strategy, a scoring scale comprised of 10 items with a maximum rating of 15 points was employed (Appendix A). This scale has been applied in similar systematic reviews following previous recommendations (A yán Pérez \& Cancela, 2014). For studies which aimed at identifying the impact of boxing on the physiological parameters of people with diverse health conditions, a 11-item checklist was created (Yes, one point; No, zero points; max. score 11 points) using the Quality Assessment Tool for O bservational Cohort and Cross-Sectional Studies (N ational H eart, Lung and Blood Institute, 2018) as a model. Items 5, 7, 9, 10 and 11 were included in order to adapt the scale to the designs of the included studies. The quality rating of this scale was interpreted as: <4, poor; 5-6, fair; 7-9, good; 10-11, excellent.

\section{Results}

A total of 499 studies were pre-selected. After screening titles and abstracts, 34 full-text papers were reviewed. Only 10 studies were selected. Of them, 2 experimental and 2 quasi-experimental were focused on the effects of boxing as a rehabilitation strategy, and 6 observational in nature, analyzed the impact of boxing on the physiological variables of people with diverse health conditions (Figure 1). No meta-analyses or prior review work could be found on this topic.

\section{O bjective and target population}

Out of the four purely experimental studies, two analyzed the effects of interventions based on non-contact boxing training, where opponents had either abdominal obesity (Cheema, Davies, Stewart, Papalia, \& Atlantis, 2015) or Parkinson's disease (Combs et al., 2011). The third study analyzed the feasibility of $\mathrm{W} \mathrm{ii}^{\mathrm{TM}}$ Boxing in pediatric populations (A bdulsatar, Walker, Timmons, \& Choong, 2013), whereas the fourth paid attention to the effects of boxing performance from a seated position in adults who had suffered a stroke (Park, Gong, \& Yim, 2017).

In relation to the six studies of a predominantly observational design, all reported changes in the heart rate $(H R)$ and energy expenditure $(E E)$ during virtual boxing practice with $A V G$ s in adults who had suffered a stroke (Hurkmans, Ribbers, Streur-Kranenburg, Stam, \& van den Berg-Emons, 2011; Kafri, M yslinski, Gade, \& Deutsch, 2014), cerebral palsy (H owcroft et al., 2012; H urkmans, van den Berg-Emons, \& Stam, 2010) or spinal cord injuries (Gaffurini et al., 2013; M at Rosly, M at Rosly, H asnan, Davis, \& Husain, 2017). Other variables under analysis included the respiratory exchange ratio (Hurkmans et al., 2010; Kafri et al., 2014), rate of perceived exertion (Howcroft et al., 2012; Hurkmans et al., 2011, 2010; Kafri et al., 2014; M at Rosly et al., 2017), muscle activation and movement quality (Howcroft et al., 2012), oxygen consumption (Gaffurini et al., 2013; Kafri et al., 2014; M at Rosly et al., 2017), pulmonary ventilation (Gaffurini et al., 2013; M at Rosly et al., 2017), practice preference ( $M$ at Rosly et al., 2017) and perception of enjoyment during practice (Kafri et al., 2014). A synthesized view of the 10 studies is shown in Table 1 


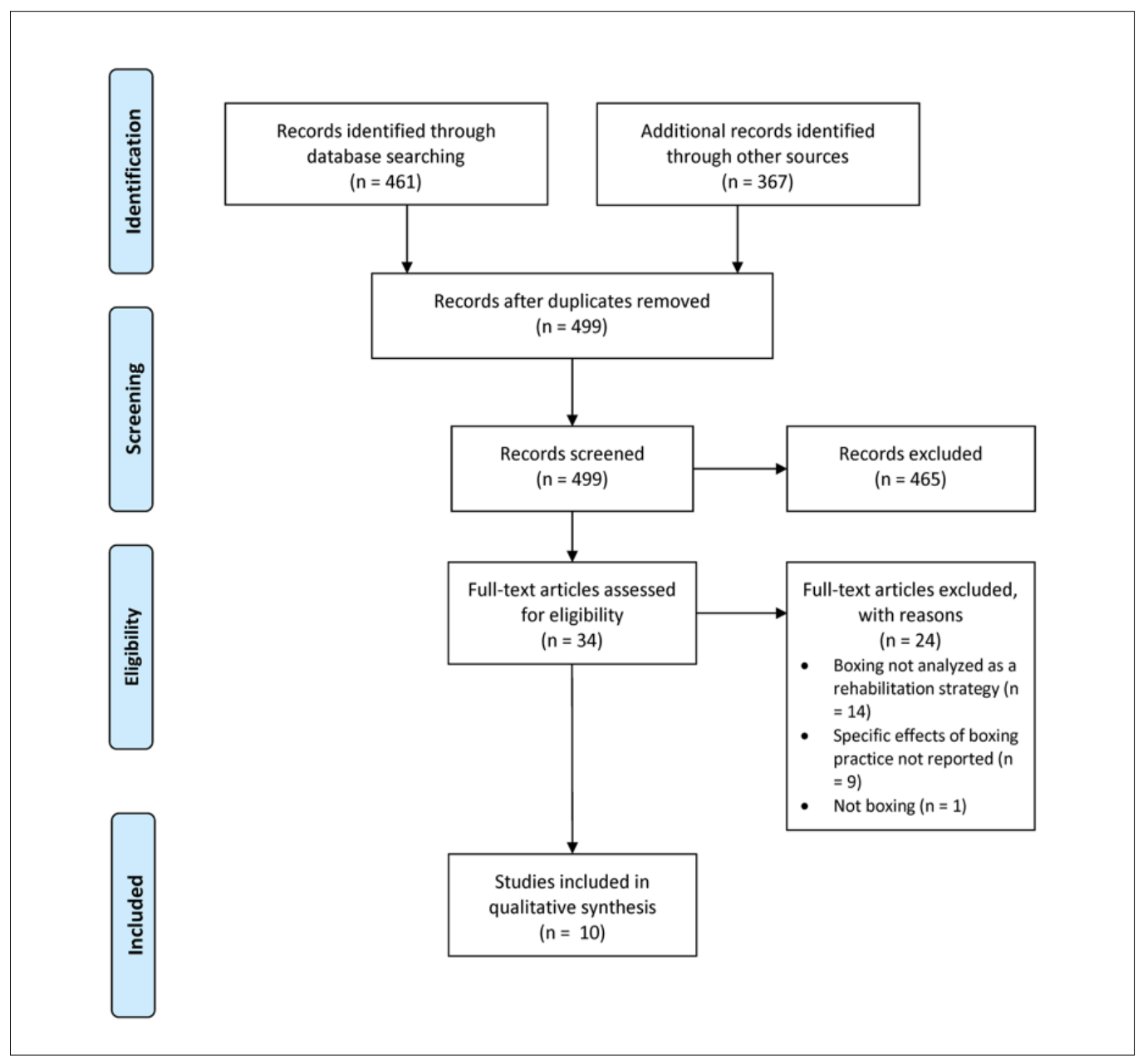

Figure 1. Flow diagram of the article screening and inclusion in this review.

\section{Characteristics of the interventions}

The duration of the programs described in the purely experimental studies varied from 1 to 12 weeks, with between one and four sessions per week lasting from 10 to 90 minutes. One study proposed a daily double session (A bdulsatar et al., 2013) and only one of the four studies included a follow-up phase (Combs et al., 2011). Boxing practice from a seated position was directed towards the improvement of upper body functions, gait and quality of life in general in patients who had suffered a stroke (Park et al., 2017), as well as to evaluate the feasibility and effectiveness of a 12-week boxing exercise program in contrast with walking at a comfortable pace in comparable physical exercise sessions. Combs et al. (2011) also analyzed the effects on balance, mobility and quality of life in patients with Parkinson, while A bdulsatar et al. (2013) focused on assessing the safety and feasibility of using AVGs as a rehabilitation strategy in children staying in a pediatric critical care unit setting.

In the case of those studies of a predominantly observational character, four studies proposed one session (Gaffurini et al., 2013; H owcroft et al., 2012; H urkmans et al., 2011, 2010), one suggested three interventions preceded by a familiarization meeting with the sample population (Kafri et al., 2014) and M at Rosly et al., (2017) proposed two sessions, but allowed participants to take part in as many as 14 if they so desired. Sessions lasted between 8 and 45 minutes. Five studies analyzed the impact of AVG boxing practice and contrasted it with other AVGs (Gaffurini et al., 2013; Howcroft et al., 2012; H urkmans et al., 2011, 2010; Kafri et al., 2014). Kafri et al.(2014) carried out an additional comparison between sports AVGs and walking at a comfortable pace. Finally, one study compared virtual boxing with real heavy bag training (M at Rosly et al., 2017). 
Table 1. General characteristics of the included studies.

\begin{tabular}{|c|c|c|c|c|c|c|c|}
\hline \multirow[t]{2}{*}{ Study } & \multicolumn{3}{|l|}{ Participants } & \multirow[t]{2}{*}{ Type of intervention (E/C) } & \multirow[t]{2}{*}{ Duration } & \multirow[t]{2}{*}{ Place } & \multirow[t]{2}{*}{ Supervisor } \\
\hline & $\begin{array}{l}\text { Health } \\
\text { condition }\end{array}$ & $\begin{array}{l}\text { M ean age } \pm \text { SD / } \\
\text { range (years) }\end{array}$ & $\begin{array}{l}\text { Distribution } \\
\text { (n; gender) }\end{array}$ & & & & \\
\hline $\begin{array}{l}\text { A bdulsatar et } \\
\text { al. (2013) }\end{array}$ & $\begin{array}{l}\text { Critically ill } \\
\text { children }\end{array}$ & $11.00 / 3-16$ & 9 & AVGs: WiiTM Boxing & 2 days & $\begin{array}{l}\text { McMaster Children's } \\
\text { Hospital }\end{array}$ & Caregivers \\
\hline $\begin{array}{l}\text { Cheema et al. } \\
\text { (2015) }\end{array}$ & Obesity & $39.00 \pm 17.00$ & $E=6 C=6$ & $\begin{array}{l}\text { E: Boxing program } \\
\text { C: Brisk walking }\end{array}$ & 12 weeks & NR & $\begin{array}{l}\text { A boxing instructor assisted in } \\
\text { designing the program. All sessions } \\
\text { were fully supervised by qualified } \\
\text { personnel. }\end{array}$ \\
\hline $\begin{array}{l}\text { Combs et al. } \\
\text { (2011) }\end{array}$ & $\begin{array}{l}\text { Parkinson's } \\
\text { Disease }\end{array}$ & $60.17 \pm 10.26$ & 6 & $\begin{array}{l}\text { Boxing drills + traditional } \\
\text { stretching, strengthening and } \\
\text { endurance exercises }\end{array}$ & $\begin{array}{l}12 \text { weeks }+ \\
\text { optional } 24 \\
\text { weeks }\end{array}$ & $\begin{array}{l}\text { Rock Steady Boxing } \\
\text { Foundation }\end{array}$ & $\begin{array}{l}1 \text { or } 2 \text { professional boxers who were } \\
\text { certified as personal trainers by the } \\
\text { National A cademy of Sports M edicine. }\end{array}$ \\
\hline $\begin{array}{l}\text { Gaffurini et al. } \\
\text { (2013) }\end{array}$ & $\begin{array}{l}\text { Spinal cord } \\
\text { injury }\end{array}$ & $40.00 \pm 8.50$ & 10 & $\begin{array}{l}\text { WiiTM Sports bowling, tennis } \\
\text { and boxing }\end{array}$ & 1 session & NR & $\mathrm{NR}$ \\
\hline $\begin{array}{l}\text { Howcroft et al. } \\
\text { (2012) }\end{array}$ & $\begin{array}{l}\text { Children with } \\
\text { cerebral palsy }\end{array}$ & $9.68 \pm 1.69$ & 17; 7 women & $\begin{array}{l}\text { AVGs: W iiTM Sports bowling, } \\
\text { tennis, boxing, and DDR } \\
\text { DisneyTM Dance Grooves. }\end{array}$ & 1 session & NR & NR \\
\hline $\begin{array}{l}\text { Hurkmans et } \\
\text { al. (2010) }\end{array}$ & $\begin{array}{l}\text { Bilateral spastic } \\
\text { cerebral palsy }\end{array}$ & $36.00 \pm 7.00$ & 8; 3 women & $\begin{array}{l}\text { AVGs: WiiT M Sports tennis } \\
\text { and boxing }\end{array}$ & 1 session & $\begin{array}{l}\text { University medical } \\
\text { center }\end{array}$ & $\begin{array}{l}\text { Two researchers stood beside the } \\
\text { participants during } W \text { ii game play. }\end{array}$ \\
\hline $\begin{array}{l}\text { Hurkmans et } \\
\text { al. (2011) }\end{array}$ & $\begin{array}{l}\text { Chronic ( } \geq 6 \\
\text { months) stroke }\end{array}$ & $\begin{array}{l}\text { Tennis: } 48.00 \text { / } \\
\text { 33-68 } \\
\text { Boxing: } 56.00 \text { / } \\
\text { 33-74 }\end{array}$ & 10 & $\begin{array}{l}\text { AVGs: WiiTM Sports tennis } \\
\text { and boxing }\end{array}$ & 1 session & $\begin{array}{l}\text { Rijndam Rehabilitation } \\
\text { Centre (N etherlands) }\end{array}$ & $\begin{array}{l}\text { Two researchers stood beside the } \\
\text { participants during W iiTM game play. }\end{array}$ \\
\hline $\begin{array}{l}\text { Kafri et al. } \\
\text { (2014) }\end{array}$ & Stroke & $\begin{array}{l}E 1=49.50 \pm \\
12.20 \\
E 2=46.80 \pm \\
6.70\end{array}$ & $\begin{array}{l}\text { E1 (stroke patients) } \\
=11 \\
\text { E2 (able-bodied } \\
\text { patients) }=8\end{array}$ & $\begin{array}{l}\text { AVGs: XboxTM Boxing, } \\
\text { WiiTM -Sports Boxing, and } \\
\text { WiiTM Fit Run and Penguin } \\
\text { games }\end{array}$ & 1 session & NR & NR \\
\hline $\begin{array}{l}\text { M at Rosly et } \\
\text { al. (2017) }\end{array}$ & $\begin{array}{l}\text { Spinal cord } \\
\text { injury }\end{array}$ & $\begin{array}{l}35.60 \pm 10.20 / \\
20-51\end{array}$ & 17; 1 woman & $\begin{array}{l}\text { H eavy bag boxing and } \\
\text { exergaming boxing ( } A \vee G)\end{array}$ & 1 session & Exercise laboratory & A certified physician and an engineer. \\
\hline $\begin{array}{l}\text { Park et al. } \\
\text { (2017) }\end{array}$ & Stroke & NR & $\begin{array}{l}E=15 \\
C=15\end{array}$ & $\begin{array}{l}\text { E: Sitting Boxing program } \\
\text { C: Physical therapy }\end{array}$ & 6 weeks & $\begin{array}{l}\text { Rehabilitation care } \\
\text { hospital (Seoul) }\end{array}$ & $\begin{array}{l}\mathrm{E}=\mathrm{NR} \\
\mathrm{C}=\text { Physical Therapist }\end{array}$ \\
\hline
\end{tabular}

2 AVG: Active video game; C: Control group; E: Experimental group; NR: Not reported. 
Regarding training loads, five studies reported on exercise intensity (Cheema et al., 2015; Gaffurini et al., 2013; Hurkmans et al., 2011, 2010; Mat Rosly et al., 2017) and four on training progress and the criteria used to plan the sessions (Abdulsatar et al., 2013; Combs et al., 2011; M at Rosly et al., 2017; Park et al., 2017). Seven studies provided information about the location in which boxing practice took place as well as the supervisors' qualifications (Abdulsatar et al., 2013; Cheema et al., 2015; Combs et al., 2011; H urkmans et al., 2011, 2010; M at Rosly et al., 2017; Park et al., 2017). The main characteristics of each program are shown in Table 2.

\section{Main findings}

Table 3 synthesizes the most relevant results of the 10 studies selected for this review. Three of the four studies that proposed intervention programs based on adapted boxing found generally positive results. Cheema et al. (2015) reported significant changes in the percentage of body fat, metabolic parameters, oxygen consumption and the participants' quality of life. Combs et al. (2011) commented that boxing practice resulted in significant improvements in balance, functional mobility, cardiovascular fitness and quality of life. Park et al. (2017) found significant improvements in upper body functionality, hand-grip strength, gait speed and quality of life. Virtual boxing practice led to improvements in every physiological parameter under analysis, as indicated in the observational studies. Video game mediated boxing proved to be a stimulus of similar magnitude to heavy bag hitting (M at Rosly et al., 2017) or walking at a comfortable pace (Kafri et al., 2014) and all participants indicated that they preferred virtual exercising.

\section{Methodological quality}

\section{Experimental and quasi-experimental studies}

All the studies featured more than two variables in the inclusion criteria, provided adequate information about the duration of the therapeutic proposal and carried out an inferential analysis of the results, although two of the studies presented more in-depth statistical data.

T wo studies (A bdulsatar et al., 2013; Combs et al., 2011) were categorized as quasi-experimental and the other two (Cheema et al., 2015; Park et al., 2017) as experimental, since a randomization process was performed, without specifying the method. No study monitored participants after the intervention. One study did not provide details about the blinding (Park et al., 2017) and the other three were single blinded (Abdulsatar et al., 2013; Cheema et al., 2015; Combs et al., 2011). Information on the causes of dropout was included in all cases (A bdulsatar et al., 2013; Cheema et al., 2015; Combs et al., 2011; Park et al., 2017), but only two referred the reliability of the instruments employed (Combs et al., 2011; Park et al., 2017). N o study clarified whether there had been a control of co-interventions in which patients may have taken part. Two of the studies did not report if the groups were homogeneous (Cheema et al., 2015; Park et al., 2017) and the other two did not feature groups to perform such comparison (A bdulsatar et al., 2013; Combs et al., 2011). The methodological quality score varied from 7 (A bdulsatar et al., 2013) to 9 (Combs et al., 2011; Park et al., 2017), with a median value of 8.5 or 'acceptable'.

\section{Observational studies}

Table 4 shows the results of the methodological quality assessment for the observational studies (Gaffurini et al., 2013; H owcroft et al., 2012; Hurkmans et al., 2011, 2010; Kafri et al., 2014; M at Rosly et al., 2017). 
Table 2. General characteristics of the interventions of the included studies.

\begin{tabular}{|c|c|c|c|}
\hline Study reference; design & Intervention Focus & Main session content $(\mathrm{E} / \mathrm{C})$ & Duration, Intensity and progression (W k/F/min) \\
\hline $\begin{array}{l}\text { Abdulsatar et al. (2013); Q uasi- } \\
\text { experimental }\end{array}$ & $\begin{array}{l}\text { Acute rehabilitation in } \\
\text { critically ill children }\end{array}$ & WiiTM Boxing & $\begin{array}{l}\text { Duration (Wk/F/min): 0/twice a day, maximum } 2 \text { days/ } 10 \\
\text { minimum. } \\
\text { Intensity: NR } \\
\text { Progression: Participants could play longer and/or more } \\
\text { frequently if they desired. }\end{array}$ \\
\hline $\begin{array}{l}\text { Cheema et al. (2015); } \\
\text { Experimental }\end{array}$ & Fat loss & $\begin{array}{l}\text { E: interval-based exercises preceded by a 5-min warm-up of } \\
\text { continuous skipping at a self-selected intensity. Intervals were } \\
\text { prescribed at 2:1 (i.e., } 2 \text { min of high intensity activity followed } \\
\text { by } 1 \text { min of rest (standing or pacing) between intervals and } \\
\text { exercises). Three intervals of each of the following five exercises } \\
\text { were performed for a total of } 30 \text { min of high-intensity effort: (1) } \\
\text { heavy bag, (2) focus mitts, (3) circular body bag, (4) footwork } \\
\text { drills, and (4) skipping. } \\
\text { C: Gradual warm-up and walking }\end{array}$ & $\begin{array}{l}\text { Duration (W k/F/min): 12/4/50 both E and C } \\
\text { Intensity: } \\
\text { E: } 30 \text { min at } 6 \mathrm{M} \mathrm{ETs,} \mathrm{excluding} \mathrm{warm-up} \mathrm{and} \mathrm{resting} \mathrm{periods.} \\
\text { During the high-intensity bouts, participants were instructed to } \\
\text { exercise at a rating of perceived exertion of } 15-17 / 20 \text {. } \\
\text { C: } 45 \text { min at } 4 \text { M ET s per minute, excluding warm-up. } \\
\text { Progression: NR }\end{array}$ \\
\hline $\begin{array}{l}\text { Combs et al. (2011); Quasi- } \\
\text { experimental }\end{array}$ & $\begin{array}{l}\text { To obtain short-term and } \\
\text { long-term improvements } \\
\text { in balance, gait, activities of } \\
\text { daily living, and quality of } \\
\text { life after the boxing } \\
\text { training program }\end{array}$ & $\begin{array}{l}\text { Warm-up of breathing and stretching exercises for major } \\
\text { muscle groups in the trunk and extremities. } 45-\text { to } 60 \text {-minute } \\
\text { circuit training regimen of function, endurance, and punching } \\
\text { activities that alternated between 3-minute training bouts and 1- } \\
\text { minute rest breaks. The session ended with a 15- to } 20 \text {-minute } \\
\text { cool-down that emphasized core stretching and strengthening } \\
\text { and breathing exercises. }\end{array}$ & $\begin{array}{l}\text { Duration (W k/F/min): } 12 \text { and optional continuation/N R/90 } \\
\text { Intensity: NR } \\
\text { Progression: The activities were advanced by encouraging patients } \\
\text { to train as intensely as they could tolerate by striving to complete } \\
\text { more repetitions during each training bout. }\end{array}$ \\
\hline $\begin{array}{l}\text { Gaffurini et al. (2013); } \\
\text { Observational }\end{array}$ & $\begin{array}{l}\text { To increase EE, HR, VO2 } \\
\text { and pulmonary ventilation }\end{array}$ & $\begin{array}{l}\text { After } 10 \text { minutes of rest, the subjects started playing each video } \\
\text { game (W iiTM Sports bowling, tennis or boxing) in a } \\
\text { randomized order, for } 10 \text { minutes with } 5 \text { minutes of rest in } \\
\text { between for cardiorespiratory recovery. }\end{array}$ & $\begin{array}{l}\text { Duration (W k/F/min): 1/1/45 } \\
\text { Intensity: For each sport, participants began on zero skill points } \\
\text { (the easiest level of competition and console opponent) and } \\
\text { progressed through the game according to the number of points } \\
\text { they were awarded. } \\
\text { Progression: NA }\end{array}$ \\
\hline $\begin{array}{l}\text { Howcroft et al. (2012); } \\
\text { Observational }\end{array}$ & $\begin{array}{l}\text { To increase EE, muscle } \\
\text { activation and quality of } \\
\text { movement }\end{array}$ & $\begin{array}{l}\text { The child played each game (WiiTM bowling, W iiTM tennis, } \\
\text { WiiTM boxing and DDR DisneyTM Dance Grooves) in a } \\
\text { randomized order for } 8 \text { minutes on a preselected beginner level } \\
\text { with a rest period of } 5 \text { minutes between each game. }\end{array}$ & $\begin{array}{l}\text { Duration (Wk/F/min): 1/1/8 } \\
\text { Intensity: NR } \\
\text { Progression: NA }\end{array}$ \\
\hline $\begin{array}{l}\text { Hurkmans et al. (2011); } \\
\text { Observational }\end{array}$ & To increase EE & $\begin{array}{l}\text { After up to } 5 \text { minutes of familiarization with the games, } \\
\text { participants rested for a minimum of } 5 \text { minutes, or until HR had } \\
\text { decreased to chair-sitting level. A fter resting, they played }\end{array}$ & Duration (W k/F/min): 1/1/40 \\
\hline
\end{tabular}




\begin{tabular}{|c|c|c|c|}
\hline Study reference; design & Intervention Focus & M ain session content $(\mathrm{E} / \mathrm{C})$ & Duration, Intensity and progression (W k/F/min) \\
\hline & & $\begin{array}{l}\text { WiiTM Sports Tennis and Boxing for } 15 \text { minutes each, in } \\
\text { random order, with a 10-minute minimum intervening rest } \\
\text { period, or until HR had decreased to chair-sitting level. }\end{array}$ & $\begin{array}{l}\text { Intensity: Each subject started the game at the beginner skill level. } \\
\text { Participants could play the game in their own manner and at their } \\
\text { own pace. } \\
\text { Progression: N R }\end{array}$ \\
\hline $\begin{array}{l}\text { Hurkmans et al. (2011); } \\
\text { Observational }\end{array}$ & To increase $\mathrm{VO} 2$ and $\mathrm{EE}$ & $\begin{array}{l}\text { After up to } 5 \text { minutes of familiarization with the games, } \\
\text { participants rested for a minimum of } 5 \text { minutes, or until HR had } \\
\text { decreased to chair-sitting level. A fter resting, they played } \\
\text { WiiTM Sports Tennis and Boxing for } 15 \text { minutes each, in } \\
\text { random order, with a 10-minute minimum intervening rest } \\
\text { period, or until HR had decreased to chair-sitting level. }\end{array}$ & $\begin{array}{l}\text { Duration (W k/F/min): 1/1/40 } \\
\text { Intensity: Participants could play the game in their own manner } \\
\text { and at their own pace. } \\
\text { Progression: N A }\end{array}$ \\
\hline $\begin{array}{l}\text { Kafri et al. (2014); } \\
\text { Observational }\end{array}$ & To increase EE & $\begin{array}{l}\text { The study consisted of } 1 \text { session for game familiarization and } 3 \\
\text { sessions for game testing. XboxTM Boxing, WiiTM -Sports } \\
\text { Boxing, W iiTM Fit Run and Penguin games were played for } 8 \text { to } \\
10 \text { minutes, with } 8 \text { to } 10 \text { minutes of rest in between. Games were } \\
\text { repeatedly loaded to achieve } 8 \text { to } 10 \text { minutes of continuous } \\
\text { activity. }\end{array}$ & $\begin{array}{l}\text { Duration (Wk/F/min): NR/3/NR } \\
\text { Intensity: NR } \\
\text { Progression: NR }\end{array}$ \\
\hline $\begin{array}{l}\text { M at Rosly et al. (2017); } \\
\text { Observational }\end{array}$ & To increase EE & $\begin{array}{l}\text { Each participant was given } 10-15 \text { min of playtime and briefing } \\
\text { prior to initiating the sessions, for familiarization. The duration } \\
\text { of each session was } 15 \text { min for both modalities of boxing, each } \\
\text { day exercising in one of them: conventional heavy bag boxing or } \\
\text { exergaming. }\end{array}$ & $\begin{array}{l}\text { Duration (W k/F/min): NR/NR/15; 2-14 sessions. } \\
\text { Intensity: The exergaming mode was set to the easiest level, since } \\
\text { none of the participants had any experience with the game-play. } \\
\text { Progression: NA }\end{array}$ \\
\hline Park et al. (2017); Experimental & $\begin{array}{l}\text { Upper limb function, } \\
\text { balance, gait, and quality of } \\
\text { life }\end{array}$ & $\begin{array}{l}\text { E: The program started with a warm-up session involving } \\
\text { breathing and stretching of the trunk and limbs for } 5 \text { minutes, } \\
\text { followed by mitt and sandbag hitting for } 10 \text { minutes, with a 2- } \\
\text { minute rest period. Thereafter, stretching of the trunk and limbs } \\
\text { was performed for } 5 \text { minutes, similarly to the warm-up. } \\
\text { C: resistance exercises and gait training. During the 30-minute } \\
\text { conventional physical therapy session, neurodevelopmental } \\
\text { treatment (NDT) and proprioceptive neuromuscular facilitation } \\
\text { (PNF) were performed for } 15 \text { minutes each. }\end{array}$ & $\begin{array}{l}\text { Duration (Wk/F/min): } 6 / 3 / 30 \text { Both } \mathrm{E} \text { and } \mathrm{C} \\
\text { Intensity: NR } \\
\text { Progression: Before the experiment, patients were trained to wear } \\
\text { gloves in the sitting position, and hit mitts and a sandbag in } \\
\text { various directions by applying different gestures. The training was } \\
\text { conducted in the sitting position in the first and second weeks. In } \\
\text { the third and fourth weeks, training was conducted below the } \\
\text { hips. During the fifth and sixth weeks, the subjects were asked to } \\
\text { hit the target while sitting and standing. }\end{array}$ \\
\hline
\end{tabular}


All but one (Gaffurini et al., 2013) specified and defined clearly the sample populations. In all of the studies, the research question or objective was clearly stated (item $n=1$ ), the participation rate of eligible people was at least $50 \%$ (item $n-3$ ). All subjects were selected or recruited from the same or similar populations and during the same time period (item $n-4$ ). The numbers of individuals at each stage of thestudy were reported (item $n-5$ ), and all thestatistical methods used in thestudy were described (item no 11). Only one study (Kafri et al., 2014) justified sample size estimation. No study reported on the validity and reliability of its evaluation instruments. Two studies analyzed the variables at baseline (Hurkmans et al., 2011, 2010). Four (Gaffurini et al., 2013; H owcroft et al., 2012; Kafri et al., 2014; M at Rosly et al., 2017) analyzed exposure to the intervention on more than one occasion. Only one study carried out a comparison between groups (Kafri et al., 2014). Overall, the methodological quality of the observational studies was considered 'good', with total scores ranging between 7 and 9 .

\section{Discussion}

This systematic review provided information from experimental studies where the effects of adapted boxing therapies on certain variables were investigated (A bdulsatar et al., 2013; Cheema et al., 2015; Combs et al., 2011; Park et al., 2017). In addition, observational studies were found, in which the main purpose was to determine the physiological effects of such therapies (Gaffurini et al., 2013; H owcroft et al., 2012; H urkmans et al., 2011, 2010; Kafri et al., 2014; M at Rosly et al., 2017), particularly regarding energy expenditure. Sample populations in the experimental studies selected showed great variability, to the point of finding different health conditions in each analysis. Observational studies provided data on three distinct population groups: patients who had suffered a stroke (H urkmans et al., 2011; Kafri et al., 2014), patients with cerebral palsy (H owcroft et al., 2012; H urkmans et al., 2010) and patients with spinal cord injuries (Gaffurini et al., 2013; M at Rosly et al., 2017). Despite the heterogeneity in terms of intervention designs and sample populations, the assessment of methodological quality indicated that the selected papers were either 'fair' (Abdulsatar et al., 2013; Cheema et al., 2015; Combs et al., 2011; Park et al., 2017) or 'good' (Gaffurini et al., 2013; Howcroft et al., 2012; Hurkmans et al., 2011, 2010; Kafri et al., 2014; M at Rosly et al., 2017).

This collection of studies did not report adverse effects on their respective patients and pointed to the existence of beneficial effects derived from boxing practice as an intervention strategy in obese (Cheema et al., 2015), Parkinson's disease (Combs et al., 2011) and even post-stroke patients (Park et al., 2017); in variables related to their level of disability, functional independence and quality of life. In fact, one of the studies (A bdulsatar et al., 2013) could not find significant improvements at the physiological or hand-grip strength levels after an intervention in pediatric patients in intensive care unit, but reported increased levels of muscular activity in the upper body compared to baseline.

The results derived from observational studies indicated that virtual boxing practice required EEs between 3.36 and 6.8 METs, which would imply that, either moderate or vigorous exercises can be tolerated by people with diverse health conditions. In this regard, some typical activities of boxing practice, like heavy bag hitting, represented an EE of $4.4 \mathrm{M} \mathrm{ET} \mathrm{s;} \mathrm{an} \mathrm{expenditure} \mathrm{comparable} \mathrm{to} \mathrm{cycling} \mathrm{or}$ Pilates (A insworth et al., 2011). These results are particularly interesting in the case of health conditions with mobility limitations, such as cerebral palsy, that hinder the possibility to achieve adequate levels of $\mathrm{EE}$ in these populations. Children with cerebral pal sy usually present slow gait velocity dueto restrictions in stride length and cadence (Honkavaara \& Rintala, 2010). While therapies like hippotherapy (H onkavaara \& Rintala, 2010) or Petra-running (Donnell, Verellen, Van de Vliet, \& Vanlandewijck, 2010) can improve these parameters; adapted boxing focused on the upper body, could be an alternative and complementing strategy in order to increase EE in this population. 
Table 3. Summary description of the aims, outcomes and findings of the included studies.

\begin{tabular}{|c|c|c|c|c|}
\hline $\begin{array}{l}\text { First author } \\
\text { and year }\end{array}$ & Aim & V ariables (measurement tools) & Findings & $\begin{array}{l}\text { Adherence; } \\
\text { dropouts }\end{array}$ \\
\hline $\begin{array}{l}\text { Abdulsatar et } \\
\text { al. (2013) }\end{array}$ & $\begin{array}{l}\text { To evaluate the safety and } \\
\text { feasibility of virtual reality exercise } \\
\text { as a novel acute rehabilitation } \\
\text { intervention in a Pediatric Critical } \\
\text { Care U nit setting. }\end{array}$ & $\begin{array}{l}\text {-Upper limb movement (accelerometer) } \\
\text { - Hand-grip strength (dynamometer and } \\
\text { vigorimeter) } \\
\text {-Severity of illness (PRISM III) } \\
\text {-Cognitive and functional ability at baseline } \\
\text { (PELOD, PCPC and POPC) } \\
\text { - Parents' and/or caregivers' perception of the } \\
\text { intervention (7-point self-administered } \\
\text { questionnaire) }\end{array}$ & $\begin{array}{l}\text { There were no adverse events attributable to the intervention. U pper limb } \\
\text { activity during W iiTM was significantly greater than the average daily activity } \\
(p=0.049) \text {. There were no statistical differences in grip strength }(p=0.20) \text { or in } \\
\text { the physiological measurements post W iiTM play as compared to baseline. The } \\
\text { caregivers' perceptions of the intervention were } 5.7 \pm 1.8 \text { for enjoyment, } 6.9 \pm \\
0.4 \text { for their impression of whether the intervention was safe and } 5.3 \pm 1.8 \text { for } \\
\text { potential benefit provided to their child. A strong correlation was found } \\
\text { between the total play-time and caregiver perception of child enjoyment } \\
(p=0.02) \text {. }\end{array}$ & $\mathrm{NR} ; 1$ \\
\hline $\begin{array}{l}\text { Cheema et al. } \\
\text { (2015) }\end{array}$ & $\begin{array}{l}\text { To assess the feasibility and } \\
\text { effectiveness of a } 12 \text {-week boxing } \\
\text { training intervention compared } \\
\text { with an equivalent dose of brisk } \\
\text { walking in obese adults for fat loss. }\end{array}$ & $\begin{array}{l}\text {-Height and weight (Calibrated scale and } \\
\text { stadiometer) } \\
\text {-BFP (calipers and } 6 \text { skinfold sites) } \\
\text { - Resting blood pressure } \\
\text {-HR (HR monitor) } \\
\text {-Arterial stiffness (SphygmoCor System) } \\
\text {-AIX (High Fidelity Tonometer) } \\
\text {-VO2max (indirect calorimetry on laboratory } \\
\text { treadmill) } \\
\text {-H ealth-related quality of life (SF-36) }\end{array}$ & $\begin{array}{l}\text { Significant improvements in BFP }(p=0.047) \text {, systolic blood pressure } \\
(p=0.026), A I X ;(p<0.001) \text {, absolute V } 02 \max (p=0.015) \text {, and Physical } \\
\text { Functioning ( } p=0.042) \text { and Vitality }(p=0.024) \text { domains of HRQ oL over time. } \\
\text { The walking group did not improve any clinical outcomes and experienced a } \\
\text { worsening of V itality }(p=0.043) \text {. }\end{array}$ & $\begin{array}{l}E: 79 \pm 15 \% \\
0 \\
C: 55 \pm 43 \% \\
2\end{array}$ \\
\hline $\begin{array}{l}\text { Combs et al. } \\
\text { (2011) }\end{array}$ & $\begin{array}{l}\text { To describe the effects of disease } \\
\text { severity and duration of boxing } \\
\text { training (short term and long } \\
\text { term) on changes in balance, } \\
\text { mobility, and quality of life for } \\
\text { patients with mild or moderate to } \\
\text { severe PD. }\end{array}$ & $\begin{array}{l}\text {-General Balance (FRT) } \\
\text {-Changes in functional standing balance over } \\
\text { time(BBS) } \\
\text {-Balance confidence (ABS } \\
\text { - M obility (TUG) } \\
\text {-W alking endurance (6M WT) } \\
\text { - Gait speed, cadence, stride length and step width } \\
\text { (GaitRite W alkway System) } \\
\text { - Activities of daily living and motor examination } \\
\text { (subscales from UPDRS and PDQL) }\end{array}$ & $\begin{array}{l}\text { Improvements were found on at least } 5 \text { of the } 12 \text { outcome measures over the } \\
\text { baseline at the } 12 \text {-week test and showed continued improvements at the } 24-\text { and } \\
\text { 36-week tests. Patients with mild PD typically showed improvements earlier } \\
\text { than those with moderate to severe PD. }\end{array}$ & $\mathrm{NR} ; 1$ \\
\hline $\begin{array}{l}\text { Gaffurini et } \\
\text { al. (2013) }\end{array}$ & $\begin{array}{l}\text { To provide evidence on the efficacy } \\
\text { of a newer intervention for general } \\
\text { health promotion in spinal cord } \\
\text { injury population. }\end{array}$ & $\begin{array}{l}\text {-V02, pulmonary ventilation, heart rate and } \\
\text { energy expenditure (metabolimeter) }\end{array}$ & $\begin{array}{l}\text { All parameters significantly increased from rest to bowling, tennis and boxing. } \\
\text { Also, all of them showed a significant positive linear trend }(p<0.0001) \text { while no } \\
\text { higher order polynomials were significant. N one of these parameters were } \\
\text { significantly affected by the sequence of gaming. }\end{array}$ & $100 \% ; 0$ \\
\hline
\end{tabular}




\begin{tabular}{|c|c|c|c|c|}
\hline $\begin{array}{l}\text { First author } \\
\text { and year }\end{array}$ & Aim & Variables (measurement tools) & Findings & $\begin{array}{l}\text { Adherence; } \\
\text { dropouts }\end{array}$ \\
\hline $\begin{array}{l}\text { Howcroft et } \\
\text { al. (2012) }\end{array}$ & $\begin{array}{l}\text { To evaluate the potential of active } \\
\text { video game (AVG) play for } \\
\text { physical activity promotion and } \\
\text { rehabilitation therapies in children } \\
\text { with cerebral palsy (CP) through a } \\
\text { quantitative exploration of energy } \\
\text { expenditure, muscle activation, } \\
\text { and quality of movement. }\end{array}$ & $\begin{array}{l}\text {-HR (HR monitor) } \\
\text {-VO2 and EE (cardiopulmonary testing unit) } \\
\text {-Upper limb muscle activations } \\
\text { (Electromiography System) } \\
\text { - U pper limb kinematics (motion capture system) } \\
\text {-Self-reported enjoyment (PACES) } \\
\text {-Self-perceived exertion (OM NI perceived } \\
\text { exertion scale) }\end{array}$ & $\begin{array}{l}\text { M oderate levels of physical activity were achieved during the dance (M ET = } \\
3.20 \pm 1.04 \text { ) and boxing (M ET }=3.36 \pm 1.50 \text { ) games. M uscle activations did not } \\
\text { exceed maximum voluntary exertions and were greatest for the boxing AVG } \\
\text { and for the wrist extensor bundle. Angular velocities and accelerations were } \\
\text { significantly larger in the dominant arm than in the hemiplegic arm during } \\
\text { bilateral play. A high level of enjoyment was reported on the PACES ( } 4.5 \pm 0.3 \\
\text { out of 5). }\end{array}$ & $\mathrm{NR} ; 0$ \\
\hline $\begin{array}{l}\text { Hurkmans et } \\
\text { al. (2011) }\end{array}$ & $\begin{array}{l}\text { To determine the energy } \\
\text { expenditure of chronic stroke } \\
\text { patients while playing W iiT M } \\
\text { Sports. }\end{array}$ & $\begin{array}{l}\text {-BM I (calibrated electronic scale) } \\
\text {-H eight (wall mounted metal anthropometer) } \\
\text {-BFP (caliper and skinfold thickness) } \\
\text {-EE during game play, sitting and standing } \\
\text { (indirect calorimeter) } \\
\text {-HR (HR monitor) } \\
\text {-Self-perceived exercise intensity (modified Borg } \\
\text { scale } 0 \text { to 10) }\end{array}$ & $\begin{array}{l}\text { EE was higher for W iiTM boxing ( } 4.1 \text { M ETs) compared to WiiTM tennis ( } 3.7 \\
\text { M ETs); however, this difference was not significant ( } p=0.50 \text { ). For all } \\
\text { participants, the EE was } \geq 3 \text { METs during boxing (range 3.4-5.7 M ETs). Only } \\
\text { one participant had energy expenditure }<3 \text { M ETs during tennis (range 2.7-5.0 } \\
\text { M ETs). The mean perceived exertion was rated higher for WiiTM Sports } \\
\text { boxing (5.3) than for tennis (4.1) ( } p=0.034 \text { ). }\end{array}$ & NR; 0 \\
\hline $\begin{array}{l}\text { Hurkmans et } \\
\text { al. (210) }\end{array}$ & $\begin{array}{l}\text { To determine energy expenditure } \\
\text { of adults with bilateral spastic } \\
\text { cerebral palsy while playing } \\
\text { WiiTM Sports tennis and boxing. }\end{array}$ & $\begin{array}{l}\text {-BMI (calibrated electronic scale) } \\
\text {-Height (wall mounted metal anthropometer) } \\
\text {-BFP (caliper and skinfold thickness) } \\
\text {-EE during game play, sitting and standing, } \\
\text {-V entilation and RER (portable, indirect } \\
\text { calorimeter) } \\
\text {-HR (H R monitor) } \\
\text {-Self-perceived exercise intensity (modified } 0 \text { to } \\
10 \text { Borg scale) }\end{array}$ & $\begin{array}{l}\text { Both W iiTM Sports tennis and boxing increased the V } 02 \text { above sitting ( } 340 \% \\
\text { and } 393 \% \text {, respectively; } p=0.012 \text { ), and above standing ( } 218 \% \text { and } 256 \% \text {, } \\
\text { respectively; } p=0.012 \text { ). Energy expenditure during Wii boxing ( } 5.0 \text { M ETs) was } \\
\text { higher compared with energy expenditure during tennis ( } 4.5 \text { M ETs); however, } \\
\text { this difference was not significant ( } p=0.069 \text { ). For all participants, the energy } \\
\text { expenditure was greater than } 3 \text { M ETs during W ii tennis (range, 3.0-6.9 M ETs) } \\
\text { and boxing (range, 3.6-6.8 M ETs) game play. The energy expenditure was } \\
\text { greater than } 6 \text { M ETs for } 1 \text { participant during tennis and boxing game play and } \\
\text { for } 1 \text { participant during boxing game play only. Perceived exertion was rated } \\
\text { higher for WiiTM Sports boxing than for tennis; however, this difference was } \\
\text { not significant ( } p=0.076 \text { ). }\end{array}$ & NR; 0 \\
\hline $\begin{array}{l}\text { Kafri et al. } \\
(2014)\end{array}$ & $\begin{array}{l}\text { To characterize the energy } \\
\text { expenditure (EE), exercise } \\
\text { intensity, and energy metabolism } \\
\text { of individuals poststroke, while } \\
\text { playing A VGs in different } \\
\text { positions, from different consoles, } \\
\text { and to compare the performance } \\
\text { with comfortable walking and with } \\
\text { able-bodied individuals. }\end{array}$ & $\begin{array}{l}\text {-VO2, M ETs and RER (portable telemetric gas } \\
\text { analysis system) } \\
\text {-HR (HR monitor) } \\
\text {-RPE (Borg Scale } 6 \text { to 20) } \\
\text { - Participant's feeling of enjoyment while playing } \\
\text { the games (a question adapted from a } \\
\text { questionnaire) }\end{array}$ & $\begin{array}{l}\text { Participants' poststroke EE ranged from } 1.81 \pm 0.74 \text { to } 3.46 \pm 1.3 \text { M ETs and was } \\
\text { lower compared with able-bodied participants for X boxTM -Boxing }(p=0.001) \text {, } \\
\text { WiiTM -Boxing in Standing }(p=0.01) \text {, Run }(p<0.001) \text {, and Penguin }(p= \\
0.001) \text {. Participants' poststroke exercise intensity ranged from } 49.8 \pm 9.3 \text { to } 64.7 \\
\pm 9.3 \% \text { predicted maximal HR and was lower compared with able-bodied } \\
\text { participants for XboxTM -Boxing ( } p=0.007) \text { and Run ( } p=0.005) \text {. For } \\
\text { participants poststroke, EE of walking at a comfortable pace did not differ from } \\
\text { boxing games in Standing or Run. For able-bodied participants only, the EE for } \\
\text { XboxTM-Boxing was higher than WiiTM Boxing }(6.5 \pm 2.6 \text { vs } 4.4 \pm 1.1 ; p= \\
0.02) \text {. EE was higher in standing versus sitting for poststroke }(p=0.04) \text { and }\end{array}$ & $\mathrm{NR} ; 0$ \\
\hline
\end{tabular}




\begin{tabular}{|c|c|c|c|c|}
\hline $\begin{array}{l}\text { First author } \\
\text { and year }\end{array}$ & Aim & Variables (measurement tools) & Findings & $\begin{array}{l}\text { A dherence; } \\
\text { dropouts }\end{array}$ \\
\hline & & & $\begin{array}{l}\text { able-bodied participants }(p=0.03) \text {. There were no significant group differences } \\
\text { for RPEs. RER of playing in sitting approached anaerobic metabolism. XboxTM } \\
\text { Boxing had the highest score of enjoyment in poststroke participants }(4.9 \pm 0.1) \\
\text { as well as both X boxTM and W iiTM Boxing AVGs in able-bodied participants } \\
(4.2 \pm 1.2) \text {. }\end{array}$ & \\
\hline $\begin{array}{l}\text { M at Rosly et } \\
\text { al. (2017) }\end{array}$ & $\begin{array}{l}\text { To compare the physiological } \\
\text { responses and user preferences } \\
\text { between conventional heavy bag } \\
\text { boxing against a novel form of } \\
\text { video game boxing, known as } \\
\text { exergaming boxing, in individuals } \\
\text { with spinal cord injury. }\end{array}$ & $\begin{array}{l}\text { - } \mathrm{HR} \text { (HR monitor) } \\
\text { - } \mathrm{VO} 2, \mathrm{EE} \text {, total } \mathrm{EE} \text {, minute ventilation and MET } \\
\text { (indirect calorimeter) } \\
\text { - RPE (Borg } 0 \text { to } 10 \text { scale) } \\
\text { - User preferences (authors' self-constructed } \\
\text { survey) }\end{array}$ & $\begin{array}{l}\text { Both exergaming and heavy bag boxing achieved moderate intensities of } \\
\text { exercise with } 4.3 \pm 1.0 \text { M ETs and } 4.4 \pm 1.0 \text { M ETs, respectively, in a sitting } \\
\text { position. Paired t-test revealed no significant differences }(p<0.05 \text {; Cohen's } \\
d=0.02-0.49 \text { ) in the physiological or perceived exertional responses between } \\
\text { the two modalities of boxing. A significant preference }(p<0.05) \text { was found for } \\
\text { the exergaming boxing. }\end{array}$ & NR; 0 \\
\hline $\begin{array}{l}\text { Park et al. } \\
\text { (2017) }\end{array}$ & $\begin{array}{l}\text { To investigate upper limb function, } \\
\text { balance, gait, and quality of life in } \\
\text { stroke patients before and after a } \\
\text { sitting boxing program. }\end{array}$ & $\begin{array}{l}\text {-U pper limb function (M FT) } \\
\text { - Handgrip strength (Hand Dynamometer) } \\
\text {-Dynamic balance (BBS) } \\
\text {-Static balance (The good Balance system) } \\
\text {-W alking ability (10M WT) } \\
\text {-Quality of life (SS-QOL) }\end{array}$ & $\begin{array}{l}\text { Significant improvements in M FT, non-affected hand grip, BBS, velocity } \\
\text { moment with eyes opened, } 10 \mathrm{MWT} \text {, and SS-QOL in the boxing group } \\
(\mathrm{p}<0.05) \text { and showed significantly greater improvements compared to the } \\
\text { control group ( } p<0.05) \text {. }\end{array}$ & $\begin{array}{l}E=N R ; 2 \\
C=N R ; 2\end{array}$ \\
\hline \multicolumn{5}{|c|}{$\begin{array}{l}\text { 6M W T: Six-M inute W alk Test; 10M WT: 10-m W alk Test; AIX: Augmentation Index; ABS: Activities-specific Balance Confidence Scale; AVG: Active video game; BBS: Berg Balance Scale; BFP: Body } \\
\text { Fat Percentage; BM I: Body M ass Index; D2-R: d2 Test of attention-Revised; FRT: Functional Reach Test; HPTs: H eat pain thresholds; M FT: The M anual Functional Test; HRQ oL: H ealth-Related } \\
\text { Quality of Life; NR: N ot Reported; PACES: Physical Activity Enjoyment Scale; PCCU: Pediatric Critical Care U nit; PCPC: Pediatric C erebral Performance Category; PD: Parkinson's Disease; PDQL: } \\
\text { PD-Specific Disability and Q uality of Life; PELOD: Pediatric logistic organ dysfunction; POPC: Pediatric O verall Performance Category; PPTs: Pressure pain thresholds; PRISM III: Pediatric risk of } \\
\text { mortality; RER: Respiratory Exchange Ratio; RPE: Rate of Perceived Exertion; SS-Q OL: Stroke-Specific Quality of Life questionnaire; TUG: Timed "Up \& Go" Test; UPDRS: Unified Parkinson's Disease } \\
\text { Rating Scale; V O2: Oxygen Consumption; VO2max: M aximum Oxygen Consumption. }\end{array}$} \\
\hline
\end{tabular}


There is evidence to suggest that boxing may be perceived as a high-risk activity (Hermand et al., 1999). In contrast, none of the selected studies reported adverse effects after the intervention and the number of dropouts was quite low, which provides evidence that reduces the expected risk perception. A nother related aspect would be that of the participants' motivation and appeal of the therapeutic program, which are two fundamental characteristics to favor adherence and predisposition to complete the intervention, and even moreso in the case of peoplewith diverse health conditions (Lui \& Hui, 2009). In this line, Kafri et al. (2014) measured the level of enjoyment during the sessions and showed that, in both groups, the highest scores were registered in the case of boxing AVGs. Similarly, the caregivers in one of the studies (A bdulsatar et al., 2013) reported high perceptions of enjoyment during AVG-based interventions in the context of a pediatric intensive care unit. It should be noted that $M$ at Rosly et al. (2017) indicated participants' preference for boxing AVGs rather than actual mitt or heavy bag hitting.

Despite the conclusions drawn by this systematic review, and the 'acceptable' or 'good' methodological quality of the selection, these are not exempt from limitations which may prevent direct transference to physical exercise program design in populations with diverse health conditions. Firstly, regarding the included studies, the samples were small both in experimental and observational studies (Gaffurini et al., 2013; H owcroft et al., 2012; H urkmans et al., 2011, 2010; K afri et al., 2014; M at Rosly et al., 2017), only two were randomized and just one of them featured a control group (Cheema et al., 2015; Park et al., 2017). Also, the interventions were short in general; therefore, arguments about potential improvements or design adequacy might have been influenced by this characteristic. In addition, the absence of a follow-up phase in experimental studies did not allow for a thorough evaluation of the variables over time. Furthermore, the lack of information regarding the control of co-interventions in which patients might have taken part for the duration of the physical exercise program could have interfered with adapted boxing proposals. Secondly, the methodological quality scales implemented did not assess the adequacy between the designs of the studies and the statistical analysis carried by the authors. Also, in these scales, the weight of the items in the total score or the established cut-off points could be debated. Thirdly, the existence of certain methodological limitations inherent to the review design-e.g. language restrictions, gray literature not reviewed or publication bias-should be considered as well.

\section{Conclusions}

The practice of adapted boxing in people with diverse health conditions may be applied as a feasible rehabilitation strategy with positive effects on cardiovascular fitness, upper body strength, body composition, coordination and parameters such as gait independence and gait speed. AVG virtual programs of adapted boxing stand as an alternative which is motivating and attractive for participants, leading to positive impacts on the user's health and providing incentives to combat sedentary lifestyles and problems derived from obesity and functional independence deterioration. Adapted boxing for rehabilitation purposes may contribute to comply with the international recommendations about physical activity and health (WHO, 2015).

\section{Perspectives}

A dapted boxing is a feasible physical therapy and can lead to improvements in different people's health-related parameters with diverse health conditions. This information may be of interest for health professionals and practitioners responsible for the prescription of physical exercise as part of a rehabilitation process. In addition, the improvements in balance and mobility detected for patients with Parkinson's disease (Combs et al., 2011) could be similarly applicable to people with multiple sclerosis (Giannì, Prosperini, Jonsdottir, \& Cattaneo, 2014) or fragile older adults (A mbrose, Paul, \& H ausdorff, 2013). Nevertheless, future randomized studies with larger population samples, longer interventions, adequate follow-up periods and better control for confounding factors such as exercise contamination are necessary to determine the adequate therapeutic dosage for each health condition, and the extent of the potentially positive effects of adapted boxing. 
Table 4. M ethodological quality of the studies that analyzed the impact of boxing sessions on physiological variables.

\begin{tabular}{|c|c|c|c|c|c|c|}
\hline \multirow[b]{2}{*}{ Criteria } & \multicolumn{6}{|c|}{ References } \\
\hline & $\begin{array}{l}\text { Kafri } \\
\text { et al. } \\
\text { (2014) }\end{array}$ & $\begin{array}{c}\text { Hurkmans } \\
\text { et al. } \\
\text { (2011) }\end{array}$ & $\begin{array}{c}\text { Hurkmans } \\
\text { et al. } \\
\text { (2010) }\end{array}$ & $\begin{array}{c}\text { Gaffurini } \\
\text { et al. } \\
\text { (2013) }\end{array}$ & $\begin{array}{c}\text { Howcroft } \\
\text { et al. } \\
\text { (2012) }\end{array}$ & $\begin{array}{c}\text { Mat Rosly } \\
\text { et al. } \\
\text { (2017) }\end{array}$ \\
\hline $\begin{array}{l}\text { 1. Was the research question or objective in this paper clearly } \\
\text { stated? }\end{array}$ & Yes & Yes & Yes & Yes & Yes & Yes \\
\hline 2. Was the study population clearly specified and defined? & Yes & Yes & Yes & No & Yes & Yes \\
\hline 3. W as the participation rate of eligible persons at least $50 \%$ ? & Yes & Yes & Yes & Yes & Yes & Yes \\
\hline $\begin{array}{l}\text { 4. Were all the subjects selected or recruited from the same or } \\
\text { similar populations (including the same time period)? W ere } \\
\text { inclusion and exclusion criteria for being in the study pre- } \\
\text { specified and applied uniformly to all participants? }\end{array}$ & Yes & Yes & Yes & Yes & Yes & Yes \\
\hline $\begin{array}{l}\text { 5. Were numbers of individuals reported at each stage of the } \\
\text { study? }\end{array}$ & Yes & Yes & Yes & Yes & Yes & Yes \\
\hline $\begin{array}{l}\text { 6. Was a sample size justification, power description, or } \\
\text { variance and effect estimates provided? }\end{array}$ & Yes & No & No & No & No & No \\
\hline $\begin{array}{l}\text { 7. For each variable of interest, was information about the } \\
\text { validity and reliability of the methods of assessment reported? }\end{array}$ & No & No & No & No & No & No \\
\hline $\begin{array}{l}\text { 8. For the analyses in this paper, were the variables intended to } \\
\text { bemeasured, assessed prior to the outcome(s) being measured? }\end{array}$ & No & Yes & Yes & Yes & No & No \\
\hline $\begin{array}{l}\text { 9. Were the variables assessed more than once during the } \\
\text { intervention? }\end{array}$ & Yes & No & No & Yes & Yes & Yes \\
\hline 10. Was a comparison between groups carried out? & Yes & No & No & No & No & No \\
\hline 11. Were all the statistical methods used in the study described? & Yes & Yes & Yes & Yes & Yes & Yes \\
\hline Quality Rating (<4, poor; 5-6, fair; 7-9, good; 10-11, excellent) & 9 (good) & 7 (good) & 7 (good) & 7 (good) & 7 (good) & 7 (good) \\
\hline
\end{tabular}

\section{Author affiliations:}

1 HealthyFit Research Group, Department of Special Didactics, Faculty of Educational Sciences and Sports, University of Vigo; misanchez@uvigo.es; chemacc@uvigo.es

2 W ell-M ove Research Group, Department of Special Didactics, Faculty of Educational Sciences and Sports, Univeristy of Vigo; cayan@uvigo.es

3 Department of M ovement and Training Sciences, Faculty of Sports Sciences, U niversity of M armara/Istanbul; mesutsener54@hotmail.com

* Correspondence: M iguel A. Sánchez-Lastra; misanchez@uvigo.es; Tel.: +0034-986-80-20-54

Author Contributions: Conceptualization, CA; M ethodology, MA, MS; Formal Analysis, JC; W riting-Original Draft Preparation, M SL; W riting-Review \& Editing, CA, M SL

Funding: This research received no external funding.

Conflicts of Interest: The authors declare no conflict of interest. 


\section{Appendix}

A ppendix A. M ethodological quality assessment scale for experimental studies.

\begin{tabular}{|c|c|}
\hline Items & Score criteria \\
\hline Randomization & 0, no; 1 , yes. \\
\hline Follow-up & 0, no; 1 , yes. \\
\hline M atching procedure & $\begin{array}{l}\text { 1, two or fewer variables as inclusion criteria; } 2 \text {, more than two } \\
\text { variables as inclusion criteria. }\end{array}$ \\
\hline Blinding & 1 , single; 2 , double \\
\hline Dropouts analysis & $\begin{array}{l}0 \text {, not described; } 1 \text {, described in half the groups; } 2 \text {, described in all } \\
\text { the groups. }\end{array}$ \\
\hline M easuring instruments & $\begin{array}{l}0 \text {, there is no reference to the validity of the instruments used; } 1 \text {, } \\
\text { there is reference to the validity of the instruments used. }\end{array}$ \\
\hline Co-interventions & $\begin{array}{l}0 \text {, there is no control of parallel interventions in the experimental } \\
\text { group; } 1 \text {, there is control of one parallel intervention in the } \\
\text { experimental group; } 2 \text {, there is control of two or more parallel } \\
\text { interventions in the experimental group. }\end{array}$ \\
\hline Patient characteristics & 0, no group homogeneity; 1, statistical group homogeneity. \\
\hline Dose of therapy & $\begin{array}{l}0 \text {, intervention time is not described; } 1 \text {, intervention time is } \\
\text { described. }\end{array}$ \\
\hline Statistics & $\begin{array}{l}0 \text {, results are not statistically described; } 1 \text {, the statistical inference of } \\
\text { the results is described, p); } 2 \text {, the statistic inference of the results is } \\
\text { described including the final } n \text { of the groups. }\end{array}$ \\
\hline M ethodological quality score & 0-6, poor; 7-9, fair; 10-12, good; 13-15, excellent. \\
\hline
\end{tabular}

References

A bdulsatar, F., Walker, R. G., Timmons, B. W ., \& Choong, K. (2013). "W ii-Hab" in critically ill children: a pilot trial. Journal of Pediatric Rehabilitation M edicine, 6(4), 193-204. https://doi.org/10.3233/PRM -130260

Ainsworth, B. E., H askell, W . L., Herrmann, S. D., M eckes, N., Bassett, D. R., Tudor-Locke, C., ... Leon, A. S. (2011). 2011 Compendium of Physical Activities: A second update of codes and M ET values. M edicine \& Science in Sports \& Exercise, 43(8), 1575-1581. https://doi.org/10.1249/M SS.0b013e31821ece12

A mbrose, A. F., Paul, G., \& H ausdorff, J. M . (2013). Risk factors for falls among older adults: A review of the literature. M aturitas, 75(1), 51-61. https://doi.org/10.1016/j.maturitas.2013.02.009

A yán Pérez, C., \& Cancela, J. M . (2014). Effectiveness of water-based exercise in people living with Parkinson's disease: a systematic review. European Review of Aging and Physical Activity, 11(2), 107-118. https://doi.org/10.1007/s11556-013-0135-7

Byrnes, K., W u, P.-J., \& W hillier, S. (2018). Is Pilates an effective rehabilitation tool? A systematic review. Journal of Bodywork and M ovement Therapies, 22(1), 192-202. https://doi.org/10.1016/j.jbmt.2017.04.008

Chaabène, H., Tabben, M., M kaouer, B., Franchini, E., Negra, Y., Hammami, M., ... Hachana, Y. (2015). A mateur boxing: Physical and physiological attributes. Sports M edicine, 45(3), 337-352. https://doi.org/10.1007/s40279-014-0274-7

Cheema, B. S., D avies, T. B., Stewart, M ., Papalia, S., \& A tlantis, E. (2015). The feasi bility and effectiveness of high-intensity boxing training versus moderate-intensity brisk walking in adults with abdominal obesity: a pilot study. BM C Sports Science, M edicine and Rehabilitation, 7(1), 3. https://doi.org/10.1186/2052-1847-7-3 
Combs, S. A., Diehl, M . D., Staples, W. H ., Conn, L., Davis, K., Lewis, N., \& Schaneman, K. (2011). Boxing training for patients with Parkinson's disease: A Case Series. Physical Therapy, 91(1), 132 142. https://doi.org/10.2522/ptj.20100142

Dijkers, M .P. , M urphy, S. L. , \& K rellman, J. (2012). Evidence-based practice for rehabilitation professionals: Concepts and controversies. Archives of Physical M edicine and Rehabilitation, 93(8 Suppl), S164-S176. https://doi.org/10.1016/j.apmr.2011.12

D onnell, R. O., V erellen, J., V an de Vliet, P., \& Vanlandewijck, Y. (2010). Kinesiologic and metabolic responses of persons with cerebral palsy to sustained exercise on a petra race runner. European Journal of A dapted Physical Activity, 3(1), 7-17. https://doi.org/10.5507/euj.2010.001

Gaffurini, P., Bissolotti, L., Calza, S., Calabretto, C., Orizio, C., \& Gobbo, M. (2013). Energy metabolism during activity-promoting video games practice in subjects with spinal cord injury: evidences for health promotion. European J ournal of Physical and Rehabilitation M edicine, 49(1), 23-29.

Giannì, C., Prosperini, L., Jonsdottir, J., \& Cattaneo, D. (2014). A systematic review of factors associated with accidental falls in people with multiplesclerosis: a meta-analytic approach. Clinical Rehabilitation, 28(7), 704-716. https://doi.org/10.1177/0269215513517575

H ermand, D., M ullet, E., \& Rompteaux, L. (1999). Societal risk perception among children, adolescents, adults, and elderly people. Journal of Adult Development, 6(2), 137-143. https://doi.org/10.1023/A:1021676909857

H iggins, J. P., \& Green, S. (Eds.). (2008). Cochrane Handbook for Systematic Reviews of Interventions: Cochrane Book Series. https://doi.org/10.1002/9780470712184

H onkavaara, M ., \& Rintala, P. (2010). The influence of short term, intensive hippotherapy on gait in children with cerebral palsy. European Journal of Adapted Physical Activity, 3(2), 29-36. https://doi.org/10.5507/euj.2010.007

H owcroft, J., Klejman, S., Fehlings, D., W right, V ., Zabjek, K., Andrysek, J., \& Biddiss, E. (2012). Active video game play in children with cerebral palsy: potential for physical activity promotion and rehabilitation therapies. Archives of Physical M edicine and Rehabilitation, 93(8), 1448-1456. https://doi.org/10.1016/j.apmr.2012.02.033

H urkmans, H. L., Ribbers, G. M., Streur-Kranenburg, M . F., Stam, H. J., \& van den Berg-Emons, R. J. (2011). Energy expenditure in chronic stroke patients playing W ii Sports: a pilot study. Journal of N euroEngineering and Rehabilitation, 8(1), 38. https://doi.org/10.1186/1743-0003-8-38

H urkmans, H. L., van den Berg-Emons, R. J., \& Stam, H. J. (2010). Energy expenditure in adults with cerebral palsy playing W ii sports. A rchives of Physical M edicine and Rehabilitation, 91(10), 1577_ 1581. https://doi.org/10.1016/j.apmr.2010.07.216

Jahnke, R., Larkey, L., Rogers, C., Etnier, J., \& Lin, F. (2010). A comprehensive review of health benefits of qigong and tai chi. American Journal of Health Promotion: AJHP, 24(6), el-e25. https://doi.org/10.4278/ajhp.081013-LIT-248

Johannsen, N. M., Swift, D. L., Lavie, C. J., Earnest, C. P., Blair, S. N., \& Church, T. S. (2016). Combined Aerobic and Resistance Training Effects on Glucose H omeostasis, Fitness, and Other M ajor H ealth Indices: A Review of Current Guidelines. Sports M edicine, 46(12), 1809-1818. https://doi.org/10.1007/s40279-016-0548-3

Kafri, M., M yslinski, M . J., Gade, V. K., \& Deutsch, J. E. (2014). Energy expenditure and exercise intensity of interactive video gaming in individuals poststroke. N eurorehabilitation and Neural Repair, 28(1), 56-65. https://doi.org/10.1177/1545968313497100

Lee, D., Psotta, R., \& V agaja, M . (2016). M otor skills interventions in children with developmental coordination disorder: A review study. European Journal of Adapted Physical Activity, 9(2), 20-29. https://doi.org/10.5507/euj.2016.007 
Lui, K. C., \& Hui, S. S. C. (2009). Participation in and adherence to physical activity in people with physical disability. H ong Kong Physiotherapy Journal, 27(1), 30-38. https://doi.org/10.1016/S10137025(10)70006-3

M at Rosly, M ., M at Rosly, H., H asnan, N ., Davis, G. M ., \& H usain, R. (2017). Exergaming boxing versus heavy-bag boxing: are these equipotent for individuals with spinal cord injury? European Journal of Physical and Rehabilitation M edicine, 53(4), 527-534. https://doi.org/10.23736/S19739087.17.04456-2

N ational Heart, Lung, and Blood Institute. (N HLBI). (2018). Study Quality Assessment Tools, National H eart, Lung, and Blood Institute (N HLBI). Retrieved O ctober 1, 2018, from https://www.nhlbi.nih.gov/health-topics/study-quality-assessment-tools

N augle, K. E., N augle, K. M ., \& W ikstrom, E. A . (2014). Cardiovascular and affective outcomes of active gaming: using the nintendo wii as a cardiovascular training tool. Journal of Strength and Conditioning Research, 28(2), 443-451. https://doi.org/10.1519/JSC.0b013e31829999c3

Park, J., Gong, J., \& Yim, J. (2017). Effects of a sitting boxing program on upper limb function, balance, gait, and quality of life in stroke patients. NeuroRehabilitation, 40(1), 77-86. https://doi.org/10.3233/NRE-161392

Pedersen, B. K., \& Saltin, B. (2015). Exercise as medicine - Evidence for prescribing exercise as therapy in 26 different chronic diseases. Scandinavian J ournal of M edicine and Science in Sports, 25, 1-72. https://doi.org/10.1111/sms.12581

Penedo, F. J., \& Dahn, J. R. (2005). Exercise and well-being: a review of mental and physical health benefits associated with physical activity. Current Opinion in Psychiatry, 18(2), 189-193.

Rhodes, R. E., \& Fiala, B. (2009). Building motivation and sustainability into the prescription and recommendations for physical activity and exercise therapy: the evidence. Physiotherapy Theory and Practice, 25(5-6), 424-441.

Ross, A., \& Thomas, S. (2010). The health benefits of yoga and exercise: a review of comparison studies. The Journal of Alternative and Complementary M edicine, 16(1), 3-12. https://doi.org/10.1089/acm.2009.0044

Sanders, G. J., Peacock, C. A., Barkley, J. E., Gish, B., Brock, S., \& V olpenhein, J. (2015). H eart Rate and Liking During "Kinect Boxing” Versus “Wii Boxing”: The Potential for Enjoyable Vigorous Physical Activity Videogames. Games for Health Journal, 4(4), 265-270. https://doi.org/10.1089/g4h.2014.0068

Strassel, J. K., Cherkin, D. C., Steuten, L., Sherman, K. J., \& V rijhoef, H. J. M . (2011). A systematic review of the evidence for the effectiveness of dance therapy. Alternative Therapies in $\mathrm{H}$ ealth and M edicine, 17(3), 50-59.

U stün, T. B., Chatterji, S., Kostansjek, N ., \& Bickenbach, J. (2003). W HO 's ICF and functional status information in health records. Health care financing review, 24(3), 77-88.

W orld Health Organization (2001). International Classification of Functioning, Disability And Health: ICF. Geneva: W orld H ealth Organization.

W orld Health Organization (2010). G lobal recommendations on physical activity for health. Geneva: W orld Health Organization.

(C) 2020 by the authors. Submitted for possible open access publication under the terms and conditions of the Creative Commons Attribution (CC BY) license (http://creativecommons.org/licenses/by/4.0/). 